\title{
Demographic and lifestyle characteristics of functional food consumers and dietary supplement users
}

\author{
Nynke de Jong ${ }^{1}$, Marga C. Ocké ${ }^{1}$, Hester A. C. Branderhorst ${ }^{2}$ and Roland Friele ${ }^{2}$ \\ ${ }^{1}$ Department of Chronic Diseases Epidemiology, National Institute of Public Health and the Environment, Bilthoven, \\ P.O. Box 1, 3720 BA, The Netherlands \\ ${ }^{2}$ NIVEL, the Netherlands Institute for Health Services Research, Utrecht, The Netherlands
}

(Received 18 March 2002 - Revised 16 September 2002 - Accepted 18 September 2002)

\begin{abstract}
Functional foods and/or supplements may be used in the context of a healthy lifestyle or as a means to compensate for an unhealthy lifestyle. Adverse long-term and/or cumulative effects of functional food or supplement intake are of public health concern; it is therefore important to identify functional food and supplement users. The present study compared Dutch functional food and supplement consumers with non-consumers with regard to demographic and lifestyle factors. The consumption of the most common functional foods and supplements in 2000 was studied (yoghurt with extra lactic acid bacteria, cholesterol-lowering margarine, lemonade and sweets with extra vitamins and minerals, milk and margarine with extra $\mathrm{Ca}$, Ca tablets, multivitamin and mineral supplements, and Echinacea supplements). Data were obtained from selfadministered questionnaires filled in by a consumer panel, aged 19-91 years (response rate $76 \%, n 1183$ ), representative of the Dutch population. The number of daily consumers of functional foods or supplements appeared to be relatively low (daily use of multivitamin and mineral supplements, 20\%; all other products, 3-9\%). Explanatory variables depended on the type of product; but gender, age, education, and vegetable intake were significant factors in the logistic regression model. Consumption of cholesterol-lowering margarines was more likely to be reported by individuals with a poorer subjective health (odds ratio 2.62 (95\% CI 1.15, 6.05)) and by smokers (odds ratio 2.93 (95\% CI 1.34, 6.40)). In conclusion, determinants of functional food or supplement use depended on the type of product, so generalisation of consumer characteristics over different foods is not legitimate. In addition to research on lifestyle factors, surveys about consumers' attitudes, norms and knowledge regarding functional foods in relation to actual dietary patterns and health risk profiles are necessary.
\end{abstract}

Functional foods: Dietary supplements: Demography and lifestyle: Functional food intake determinants: General population

For the food industry, the driving force behind the functional food concept is to create a market niche to commercialise innovative products claiming beneficial physiological effects beyond those ordinarily associated with typical nutrients. Consequently, in the next few decades a range of newly developed functional foods will be introduced, accompanied by media messages and advertisements on the need to 'optimise' nutrition, health and quality of life (Wrick, 1995; Jacobson \& Silverglade, 1999; Sparling \& Anderson, 2001). This strategy will be attractive because there is a powerful psychological appeal to consumers to improve or maintain health in a proactive and convenient approach (Hilliam, 1996; Milner, 1999). In addition, population aspects such as the increasing wealth of the developed world inhabitants, the ageing of the population and the accompanying increase in health problems contribute to the increasing interest in functional foods (Hasler, 2000; Sparling \& Anderson, 2001).

There are indications that dietary supplements are likely to be used by individuals who do not fit in the initial target group: individuals who already have a healthy lifestyle are more likely to buy dietary supplements (Kirk et al. 1999; Radimer et al. 2000; Greger, 2001). Yet, this is not confirmed by all investigators (Wallström et al. 1996). Individuals might actually use functional foods and/or dietary supplements as a means to compensate for an unhealthy lifestyle (Hilliam, 1996; Kirk et al. 1999; Radimer et al. 
2000). The potential to self-medicate with a range of foods and supplements without any control mechanism is a key public health issue (Hathcock, 1997; Kirk et al. 1999; Kristal et al. 2001). Different functional foods for different segments of the population have been marketed, but it is not known who is using the foods, how frequent those foods are used and what characterises these consumers. For general education purposes (Childs \& Poryzees, 1998), but also for the monitoring of safety and efficacy of functional foods and supplements consumption in a future post-launch monitoring system, it is vital to identify and characterise (potential) functional food users and to investigate their knowledge, their norms and motivation to use such products. The present study explored opinions from Dutch consumers regarding different functional foods and dietary supplements as well as the association between demographic variables, several lifestyle characteristics, and actual functional food and/or dietary supplement consumption.

\section{Methods \\ Participants}

The sample invited for participation in the present study consisted of the 1552 members of the 'Dutch Health Care Consumer Panel'. This panel was established in 1991 by NIVEL (the Netherlands Institute for Health Services Research) and the Dutch Consumer Association with the aim of obtaining information on patients and consumers regarding public health issues. This information is available to policy makers and several consumer and patient organisations. Twice yearly, a questionnaire focusing on a specific topic is distributed to panel members. At the beginning of the year 2000 a self-administered questionnaire concerning functional foods and dietary supplements was distributed.

The panel is selected to be representative of the Dutch population as a whole regarding age, gender, household composition, health-care insurance services and geographic distribution. Approximately $20 \%$ of the panel is renewed on a yearly basis in order to overcome panel mortality and bias due to panel effects (Friele et al. 1996). In the present study 1183 members participated, which is a response rate of $76 \%$.

\section{Questionnaires}

At the time of study there were only a few functional foods available on the Dutch market, in addition to dietary and herbal supplements. The products that were included in the questionnaire were the most popular functional products in the Netherlands at that time and were divided into the following sections: (a) milk and/or margarine with extra $\mathrm{Ca}$; (b) yoghurt with special lactic acid bacteria; (c) margarine with added stanols $\left(\right.$ Benecol $\left.^{\circledR}\right)$; (d) supplements containing Echinacea; (e) Ca tablets; (f) lemonade and/or sweets with added vitamins and/or minerals; (g) multivitamin and mineral supplements. Definitions of a functional food and a supplement have been described beforehand: i.e. a functional food is a food with an extra
Table 1. Translations of the propositions in the questionnaire*

1. I think that the beneficial effects of product ' $x x$ ' has been proven sufficiently

2. I think that product ' $x x^{\prime}$ ' is safe

3. I think that product ' $x x^{\prime}$ ' is safer than a drug with a comparative function

4. I think that I would use product ' $x x$ ' if I suffered from the specific aimed health condition

5. I think that everybody can safely use product ' $x x^{\prime}$ ' in unlimited amounts

6. I am of the opinion that product ' $x x^{\prime}$ ' is too expensive

7. Instead of product ' $x x^{\prime}$ ' I would like to use drugs with the same beneficial effect

8. Instead of product ' $x x^{\prime}$ ' I would like to use a dietary supplement with the same beneficial effect

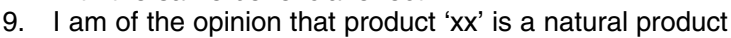

10. I think that consumption of product ' $x x^{\prime}$ ' is an easy way to stay healthy

11. I think that product ' $x x^{\prime}$ ' is environmentally friendly

*For each statement, subjects rated whether they 'completely agreed', 'agreed', 'disagreed' or 'completely disagreed'.

nutritional value on top of the normal nutritional value of that particular food, and a supplement is a pill, coated tablet or drops with a health-enhancing function. The questions were repeated for each food or supplement and focused on the frequency of consumption, opinions about the supposed active component, opinions about the target group and opinions about the food or supplement being a drug or a food. As well, eleven statements were presented for each food or supplement in the different sections and subjects were asked to rate on a 4-point scale whether they 'fully agreed', 'agreed', 'disagreed', or 'completely disagreed' (see Table 1). A neutral statement was not allowed in order to force an opinion. In addition, views about the current functional food trend, the role of the Dutch consumer association and the regulating activities of the government were asked.

With regard to lifestyle characteristics, information was obtained about: smoking; excessive alcohol consumption; vegetable, fibre and fat intake; daily physical activity (number of hours spent cycling, walking, gardening, or sport/week); as well as subjective health. Excessive alcohol consumption was assessed as the frequency of intake of six glasses or more/d. Subjects consuming six glasses or more on $1 \mathrm{~d}$ at least monthly were coded in a different category to subjects consuming six or more glasses/d less frequently or never. A short dietary questionnaire was developed using results from an earlier validation study of an extensive food frequency questionnaire. The study revealed which items were the most important explanatory variables for vegetable, fibre and fat intake (Ocké et al. 1997). Detailed information about the food-related questions is available from N.D.J. Information on demographic variables (for example, age, gender, marital status, education and income) was obtained from earlier panel questionnaires.

\section{Statistical methods}

Statistical analyses were performed using SPSS for windows, version 9.0 (SPSS Inc., Chicago, IL). For descriptive 
purposes absolute numbers and percentages of participants were calculated for demographic and lifestyle characteristics. Categories for age, education, income, subjective health, excessive alcohol intake, and activity pattern were constructed either based on the distribution of the data or based on logical cut-off points. With regard to the dietary variables individuals were categorised as low, moderate or high consumers of vegetables, fibre and fat. Because consumers of functional foods and supplements were compared with non-consumers, logistic regression methods were used. Crude and adjusted odds ratios (OR; and $95 \% \mathrm{CI}$ ) were calculated to examine the effects of the demographic and lifestyle variables on use $(=1)$ or nonuse $(=0)$ of functional foods or dietary supplements. To adjust the OR all variables were entered simultaneously into the model in order to account for the effects of all other covariates. Similar analyses were performed in which OR of frequent use (at least twice-monthly; =1) or seldom or no use $(=0)$ of functional foods or supplements were evaluated. The number of respondents included in the analyses may differ according to the food or dietary supplement or because of missing data.

\section{Results}

The demographic and lifestyle characteristics of the study participants are presented in Table 2. There were more female respondents than men. The majority was living with a partner, did not smoke and never or seldom drank six glasses or more of alcohol/d. About $25 \%$ of the participants had a low education level and $21 \%$ reported to have a gross household income in the lowest category. In total $21 \%$ assessed their health as moderate to poor, and the same proportion considered their physical activity level to be $1 \mathrm{~h}$ or less/week.

Our panel was compared with the general Dutch population for several characteristics. There were slightly more women in our study $(57 \%$ in the panel v. $51 \%$ in the Dutch population). The age distribution was comparable; for example, $20 \%$ in our panel was 65 years and older $v .18 \%$ in the general population, and $18 \%$ of our participants were aged between 19 and 34 years $v .23 \%$ in the general population. In 1996, $21 \%$ of the Dutch population had only primary school as their highest education, whereas $18 \%$ had a high formal education; values that are comparable to ours (25 and $21 \%$ respectively). In addition, one-third of the Dutch population are smokers ( $31 \%$ in our panel), and between 9 and $14 \%$ are classified as excessive alcohol drinkers $(16 \%$ in our panel drank six or more glasses/d at least once monthly) (Centrum voor Volksgezondheid en Toekomst Verkenningen and Nationaal Kompas Volksgezondheid, 2001).

Of the participants, $20 \%$ used multivitamin and mineral supplements daily (Table 3 ). The number of daily consumers of the other foods or supplements included in the study were much lower; i.e. between 3 and $9 \%$. Among the panel members, $30 \%$ frequently (at least once weekly) used one functional food or supplement, $18 \%$ frequently used two different foods or supplements, $7 \%$ frequently used three different products, and about $4 \%$ used four or more products frequently. The relatively
Table 2. Characteristics of the study participants

\begin{tabular}{|c|c|c|}
\hline \multirow[b]{2}{*}{ Characteristic } & \multicolumn{2}{|c|}{ Respondents } \\
\hline & $n$ & $\%$ \\
\hline \multicolumn{3}{|l|}{ General } \\
\hline \multicolumn{3}{|l|}{ Gender } \\
\hline Male & 473 & 40 \\
\hline Female & 678 & 57 \\
\hline Unknown & 32 & 3 \\
\hline \multicolumn{3}{|l|}{ Age (years) } \\
\hline $19-34$ & 218 & 18 \\
\hline $35-49$ & 428 & 36 \\
\hline $50-64$ & 293 & 25 \\
\hline 65 and over & 235 & 20 \\
\hline Unknown & 9 & 1 \\
\hline \multicolumn{3}{|l|}{ Marital status } \\
\hline Married & 733 & 62 \\
\hline Single & 236 & 20 \\
\hline Divorced & 110 & 9 \\
\hline Widowed & 75 & 6 \\
\hline Unknown & 29 & 3 \\
\hline \multicolumn{3}{|l|}{ Education level } \\
\hline Low & 299 & 25 \\
\hline Middle & 593 & 50 \\
\hline High & 250 & 21 \\
\hline Unknown & 41 & 4 \\
\hline \multicolumn{3}{|c|}{ Yearly income (Dutch guilders ${ }^{\star}$ ) } \\
\hline Below 40000 & 248 & 21 \\
\hline $40000-60000$ & 274 & 23 \\
\hline $60000-80000$ & 178 & 15 \\
\hline 80000 and over & 244 & 21 \\
\hline Unknown & 239 & 20 \\
\hline \multicolumn{3}{|l|}{ Subjective health } \\
\hline Good & 771 & 65 \\
\hline Moderate to bad & 253 & 21 \\
\hline Unknown & 159 & 13 \\
\hline \multicolumn{3}{|l|}{ Smoking } \\
\hline Yes & 365 & 31 \\
\hline No & 805 & 68 \\
\hline Unknown & 13 & 1 \\
\hline \multicolumn{3}{|l|}{ Dietary factors } \\
\hline \multicolumn{3}{|l|}{ Vegetable intake } \\
\hline Low & 295 & 25 \\
\hline Moderate & 546 & 46 \\
\hline High & 314 & 27 \\
\hline Unknown & 28 & 2 \\
\hline \multicolumn{3}{|l|}{ Fibre intake } \\
\hline Low & 332 & 28 \\
\hline Moderate & 479 & 40 \\
\hline High & 349 & 30 \\
\hline Unknown & 23 & 2 \\
\hline \multicolumn{3}{|l|}{ Fat intake } \\
\hline Low & 307 & 26 \\
\hline Moderate & 308 & 26 \\
\hline High & 307 & 26 \\
\hline Unknown & 261 & 22 \\
\hline \multicolumn{3}{|l|}{ High alcohol intake† } \\
\hline Never or seldom & 974 & 82 \\
\hline At least monthly or weekly & 183 & 16 \\
\hline Unknown & 26 & 2 \\
\hline \multicolumn{3}{|l|}{ Activity pattern } \\
\hline Exercise (h/week) $\ddagger$ & & \\
\hline $0-1$ & 246 & 21 \\
\hline $2-3$ & 530 & 45 \\
\hline 4 or more & 324 & 27 \\
\hline Unknown & 83 & 7 \\
\hline
\end{tabular}

* To convert to the European Euro, divide by 2.20 .

$\dagger$ Frequency of consumption of $\geq$ six glasses/d (see p. 275).

$\ddagger$ Walking, cycling, gardening, doing odd jobs around the house, sports. 
Table 3. Frequency of consumption of seven functional foods and dietary supplements by 1183 respondents investigated in the Netherlands in the spring of the year $2000^{*}$

\begin{tabular}{|c|c|c|c|c|c|c|c|c|c|c|c|c|c|c|}
\hline & \multicolumn{2}{|c|}{$\begin{array}{c}\text { Yoghurt } \\
\text { with lactic } \\
\text { acid } \\
\text { bacteria }\end{array}$} & \multicolumn{2}{|c|}{$\begin{array}{c}\text { Cholesterol- } \\
\text { lowering } \\
\text { margarine }\end{array}$} & \multicolumn{2}{|c|}{$\begin{array}{l}\text { Lemonade } \\
\text { or sweets } \\
\text { with extra } \\
\text { vitamins } \\
\text { and } \\
\text { minerals }\end{array}$} & \multicolumn{2}{|c|}{$\begin{array}{l}\text { Foods with } \\
\text { extra Ca }\end{array}$} & \multicolumn{2}{|c|}{ Ca tablets } & \multicolumn{2}{|c|}{$\begin{array}{l}\text { Multivita- } \\
\text { min and } \\
\text { mineral } \\
\text { sup- } \\
\text { plements }\end{array}$} & \multicolumn{2}{|c|}{ Echinacea } \\
\hline & $n$ & $\%$ & $n$ & $\%$ & $n$ & $\%$ & $n$ & $\%$ & $n$ & $\%$ & $n$ & $\%$ & $n$ & $\%$ \\
\hline Daily & 33 & 3 & 31 & 3 & 37 & 3 & 69 & 6 & 101 & 9 & 231 & 20 & 65 & 6 \\
\hline $\begin{array}{l}\text { Once or several } \\
\text { times/week }\end{array}$ & 56 & 5 & 9 & 1 & 99 & 8 & 52 & 4 & 39 & 3 & 104 & 9 & 34 & 3 \\
\hline $\begin{array}{l}\text { Once or several } \\
\text { times } / \text { month }\end{array}$ & 62 & 5 & 4 & 0 & 88 & 7 & 40 & 3 & 27 & 2 & 47 & 4 & 34 & 3 \\
\hline Less than monthly & 228 & 19 & 31 & 3 & 208 & 18 & 158 & 13 & 125 & 11 & 249 & 21 & 266 & 23 \\
\hline $\begin{array}{l}\text { Frequency of use not } \\
\text { further specified }\end{array}$ & 4 & 0 & 3 & 0 & 3 & 0 & 5 & 0 & 7 & 1 & 11 & 1 & 6 & 1 \\
\hline No use at all & 581 & 49 & 498 & 42 & 400 & 34 & 684 & 58 & 702 & 59 & 446 & 38 & 324 & 27 \\
\hline Unknown & 219 & 19 & 607 & 51 & 348 & 29 & 175 & 15 & 182 & 15 & 95 & 8 & 453 & 38 \\
\hline
\end{tabular}

${ }^{*}$ For details of respondents and procedures, see Tables 1 and 2 and p. 274.

high daily consumption of the multivitamin and mineral supplements was in agreement with the fact that $61 \%$ ( $n$ 722) of the panel believed that efficacy was proven sufficiently (Table 4). Of the panel members, $59 \%$ ( $n$ 698) believed the same for the $\mathrm{Ca}$ supplements. In contrast, only $15 \%$ ( $n$ 177) believed in sufficiently proven efficacy for sweets and lemonade with extra vitamins and minerals. The participants were asked if they believed that the functional foods or supplements can be safely consumed in unlimited amounts: Ca tablets $18 \%$ ( $n$ 213); foods with added $\mathrm{Ca} 43 \%$ ( $n$ 509). Depending on the type of foods or supplements, the panel members regarded the investigated foods and supplements as easy strategies to stay healthy: $17 \%$ ( $n$ 201) for cholesterol-lowering margarine; $48 \%$ ( $n$ 568) for multivitamin and mineral supplements.

Half of the study population $(52 \%, n$ 615) was of the opinion that the development of functional foods was a positive development, while $26 \%$ (n 305) did not like

Table 4. Opinions of the respondents ( $n$ 1183) about functional foods and dietary supplements (expressed as \%) ${ }^{\star} \dagger$

\begin{tabular}{|c|c|c|c|c|c|c|c|c|c|c|c|c|c|c|}
\hline \multirow{2}{*}{$\begin{array}{l}\text { Product... } \\
\text { Statement }\end{array}$} & \multicolumn{2}{|c|}{$\begin{array}{l}\text { Yoghurt } \\
\text { with lactic } \\
\text { acid } \\
\text { bacteria }\end{array}$} & \multicolumn{2}{|c|}{$\begin{array}{l}\text { Choles- } \\
\text { terol- } \\
\text { lowering } \\
\text { margarine }\end{array}$} & \multicolumn{2}{|c|}{$\begin{array}{c}\text { Lemonade } \\
\text { or sweets } \\
\text { with extra } \\
\text { vitamins } \\
\text { and } \\
\text { minerals }\end{array}$} & \multicolumn{2}{|c|}{$\begin{array}{l}\text { Foods with } \\
\text { extra } \mathrm{Ca}\end{array}$} & \multicolumn{2}{|c|}{ Ca tablets } & \multicolumn{2}{|c|}{$\begin{array}{l}\text { Multivita- } \\
\text { min and } \\
\text { mineral } \\
\text { sup- } \\
\text { plements }\end{array}$} & \multicolumn{2}{|c|}{ Echinacea } \\
\hline & Yes & No & Yes & No & Yes & No & Yes & No & Yes & No & Yes & No & Yes & No \\
\hline $\begin{array}{l}\text { The product is more like a } \\
\text { drug than a food }\end{array}$ & 1 & 65 & 2 & 31 & 2 & 49 & 2 & 71 & 42 & 14 & 36 & 18 & 38 & 3 \\
\hline $\begin{array}{l}\text { Efficacy of the product } \\
\text { has been proven } \\
\text { sufficiently }\end{array}$ & 25 & 51 & 16 & 27 & 15 & 52 & 35 & 47 & 59 & 20 & 61 & 25 & 38 & 19 \\
\hline $\begin{array}{l}\text { The product is safer to } \\
\text { use than a drug with a } \\
\text { comparative function }\end{array}$ & 29 & 46 & 13 & 30 & 20 & 47 & 28 & 53 & 36 & 43 & 39 & 46 & 33 & 24 \\
\hline $\begin{array}{l}\text { Preference for a drug with } \\
\text { the same beneficial } \\
\text { effect instead of the } \\
\text { product }\end{array}$ & 24 & 51 & 17 & 27 & 34 & 32 & 27 & 54 & 19 & 59 & 22 & 64 & 14 & 42 \\
\hline $\begin{array}{l}\text { Unlimited use of the } \\
\text { product is safe }\end{array}$ & 37 & 40 & 22 & 23 & 24 & 43 & 43 & 39 & 18 & 61 & 19 & 67 & 22 & 35 \\
\hline $\begin{array}{l}\text { The product is too } \\
\text { expensive }\end{array}$ & 51 & 22 & 34 & 10 & 37 & 27 & 46 & 32 & 34 & 39 & 54 & 30 & 27 & 28 \\
\hline $\begin{array}{l}\text { The product is a 'natural' } \\
\text { product }\end{array}$ & 45 & 31 & 20 & 24 & 20 & 47 & 42 & 39 & 43 & 35 & 30 & 56 & 51 & 7 \\
\hline $\begin{array}{l}\text { Use of the product is an } \\
\text { easy way to stay healthy }\end{array}$ & 31 & 45 & 17 & 27 & 18 & 49 & 39 & 42 & 37 & 41 & 48 & 38 & 33 & 23 \\
\hline
\end{tabular}

* For details of respondents and procedures, see Tables 1 and 2 and p. 274.

† Missing values or answers such as 'do not know' are not presented. Yes, completely agree or agree; No, disagree or completely disagree. 
the current development (data not presented). Among those who were in favour of the concept of functional foods were (not surprisingly) more users of the products investigated (between 66 and $82 \%$, depending on the product) than non-users. Of the participants, $49 \%$ ( $n$ 578) thought that consumer organisations should focus on the safety of the products, whereas $34 \%$ ( $n$ 397) were of the opinion that the major task of these organisations should be the testing of health claims. Only $4 \%$ ( $n$ 52) wanted action for better legislation and $9 \%(n 110)$ thought that checking the content claims on the labels should be a primary task (data not presented).

In Tables 5 and 6 the crude and adjusted OR are presented respectively for consumption relative to non-consumption of the functional foods or supplements in relation to demographic and lifestyle characteristics. With the exception of the cholesterol-lowering margarine (Ben$\mathrm{ecol}^{\circledR}$ ) and the enriched lemonade and sweets, women were more likely to be consumers. $\mathrm{Ca}$ tablets were especially taken by the middle and older age groups, whereas the lemonade and/or sweets with extra vitamins and minerals were used by the youngest age group. Based on the crude results (Table 5) participants in the middle and high education groups were more likely to use supplements containing Echinacea or multivitamin and minerals than individuals with lower education. This was not true for the $\mathrm{Ca}$ tablets and other products containing extra $\mathrm{Ca}$; for example, consumption in the middle and high education groups was less likely than in the low education group. After adjustment, results were less pronounced; only multivitamin and mineral use was significantly associated with education. From the crude analyses, it appears that on average a moderate or high vegetable intake was associated with use of several functional foods and Echinacea, with the exception of multivitamin and mineral supplements. This tendency was still present in the adjusted analyses, but no longer significant for all products. In the crude analyses, a high fibre intake emerged to be associated with a less frequent use of Echinacea, and $\mathrm{Ca}$ and multivitamin and mineral supplements; but again this was not confirmed by the adjusted results. Smoking, especially, appeared to be associated with use of the cholesterol-lowering margarine, even after adjustment for the other variables. Crude OR showed that the same was true for frequent excessive alcohol users; however, after adjustment this association was no longer statistically significant.

In addition to the classification in consumption $v$. nonconsumption of functional foods and/or supplements, we performed similar adjusted analyses in which participants were divided into a group who frequently used the products (at least twice-monthly) and a group who never or rarely used those products. The same tendencies were observed, plus associations of a poor subjective health with frequent consumption of Ca-containing foods (OR $2.14(95 \%$ CI $1.21,3.81)$ ), and $\mathrm{Ca}$ supplements (OR $2.13(95 \%$ CI $1.16,3.90)$ ). In addition, frequent exercise was associated with a more frequent use of foods with extra lactic acid bacteria (OR 2.62 (95\% CI 1.07, 6.41)) and with more frequent Echinacea use (OR 2.67 (95\% CI 1.09, 6.55)).

\section{Discussion}

From the findings of the present study we conclude that the frequency of consumption of functional foods and/or dietary supplements in the Netherlands is still behind recent data presented by American investigators (Pitman \& Reinhardt, 2000). This may be explained from a time-period point of view: wholesale introduction of certain functional foods and dietary supplements occurred much later in many European countries, or at least in the Netherlands. Furthermore, Dutch consumers may be more sceptical about functional foods, which may point at differences in information programmes, but also at cultural differences in the perception of food in relation to health. A consumer survey in Britain, France and Germany showed that even within Europe clear differences in consumers' attitudes to functional foods appear (Jonas \& Beckmann, 1998), which is an interesting topic for future studies.

The fact that consumption of functional foods by our Dutch panel in the year 2000 was not widespread is a remarkable phenomenon in itself; however, it is a limitation of the study due to power reduction and should be taken into account while interpreting our findings. It is noteworthy that at least half of our panel was in favour of the functional food concept, yet reported consumption of functional foods was lower. As well, the fact that the majority of the panel believed in the proven functionality of the dietary supplements compared with much lower percentages for the investigated functional foods is of interest.

We investigated a variety of foods and supplements and it appeared that the association of demographic and lifestyle characteristics with consumption behaviour differs according to product. This may be an important reason for not generalising consumer characteristics over different foods and/or supplements. Even within the same product categories (for example, $\mathrm{Ca}$ tablets $v$. foods with extra Ca) associations varied. The relative novelty of many of the products in the Netherlands and the low consumption figures with the related power reduction may be responsible for the somewhat inconclusive results among the same product categories. Gender, age, education, vegetable intake, alcohol intake, smoking and subjective health were predictors of use of one or more products. Especially smoking and a poor subjective health were associated with cholesterol-lowering margarine use. Frequent exercise was associated with the consumption of Echinacea supplements and foods with extra lactic acid bacteria, when the OR for being a frequent consumer of these products was calculated. It would be of interest to include specific target groups in future research to find out whether stronger associations can be found in more specific groups within our population. As well, the observed associations with subjective health deserve further study. It will be of interest to confirm the associations with objective measures of health status. In addition, detailed information about actual vegetable, fibre and fat intake, instead of our indicator questions, could result in stronger associations. Whether the consumption of sweets and lemonade in the youngest age group is different for the enriched item compared with the regular alternative is another topic of interest. 


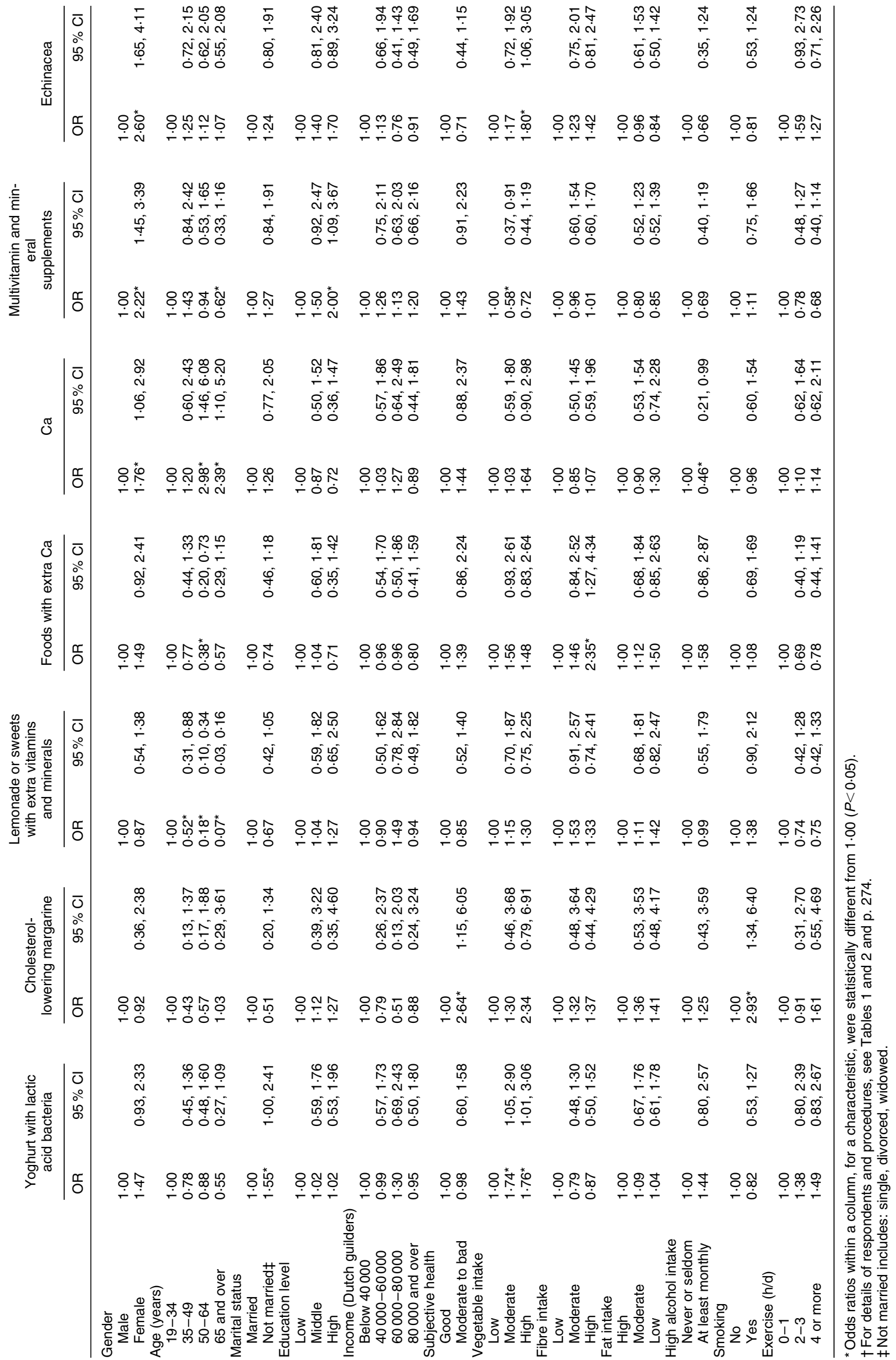


From earlier studies that investigated dietary supplement use it was concluded that supplement users are more likely to be female, better educated, affluent, non-smokers, light drinkers, and tend to have an adequate nutritional intake. This suggests that the actual supplement users are not the target group in need of extra nutrients (Block et al. 1988; Lyle et al. 1998; Patterson et al. 1998; Kirk et al. 1999; Neuhouser et al. 1999; Radimer et al. 2000; Greger, 2001). Results, however, remain somewhat inconclusive because not all data (Wallström et al. 1996; Radimer et al. 2000) completely support this hypothesis. Recently, characteristics of plant stanol ester margarine users were described in a Finnish publication (Anttolainen et al. 2001). Again, users tended to be better educated (which is often associated with a healthier diet), were urban, had a higher income and were more often married. In order to be able to compare the different studies on functional food consumption behaviour and to monitor trends over time it will be necessary to standardise research methodologies; for example, question wording and foods and supplements categorisation (Radimer et al. 2000). Also, studies in representative samples of the whole population in addition to research in non-random subgroups are necessary (Neuhouser et al. 1999). Thus far, study objectives have been defined as the attitudes of consumers (Hilliam, 1996; Childs \& Poryzees, 1998), whereas we took the actual consumption behaviour as the dependent parameter. Nevertheless, consumption was estimated from reported data and there is no evidence that the declarations made by our panel actually reflect behaviour.

The number of participants (i.e. 1183) should have been sufficient to detect an excessive use in certain segments of our panel in relation to the public health perspective. We are unable to conclude that only health-conscious individuals take functional foods; neither can we conclude that 'at risk' groups take functional foods as a means to compensate for an unhealthy lifestyle. Groups that should be followed in the future might be individuals with a poor subjective health and smokers who are, for example, more likely to use cholesterol-lowering margarines. Yet, these individuals may be over-represented in the target group of the cholesterol-lowering margarines because they may experience higher cholesterol levels.

European consumers' attitudes, norms and knowledge about functional foods, their dietary patterns and their demographic and other lifestyle characteristics deserve structured surveys based on an appropriate theoretical basis in the near future.

\section{Acknowledgements}

We wish to thank the Dutch Consumer Association, the 'Consumentenbond', for the initiative and support of the present study. We acknowledge the Netherlands Organisation for Health Research and Development (NWO) for supporting N. D. J. With gratitude we thank the 1183 participating members of the Dutch Health Care Consumer Panel.

\section{References}

Anttolainen M, Luoto R, Uutela A, Boice JD Jr, Blot WJ, McLaughlin JK \& Puska P (2001) Characteristics of users and nonusers of plant stanol ester margarine in Finland: an approach to study functional foods. Journal of the American Dietetic Association 101, 1365-1368.

Block G, Cox C, Madans J, Schreiber GB, Licitra L \& Melia N (1988) Vitamin supplement use, by demographic characteristics. American Journal of Epidemiology 127, 297-309.

Centrum voor Volksgezondheid en Toekomst Verkenningen and Nationaal Kompas Volksgezondheid (2001) National Institute of Public Health and the Environment and Ministry of Health, Welfare and Sport. http://www.rivm.nl/nationaalkompas

Childs NM \& Poryzees GH (1998) Foods that help prevent disease: consumer attitudes and public policy implications. British Food Journal 100, 419-426.

Friele RD, Bakker RHC \& Vaessen Y (1996) De Logboekjes Tegen het Licht - Bruikbaarheid van het Medisch Logboek Consumentenpanel Gezondheidszorg 1993-1995 (The logbooks Evaluate - Usefulness of the Medical Log-books in the Health Services Consumer Panel 1993-1995). Utrecht and Den Haag, The Netherlands: NIVEL/Consumentenbond.

Greger JL (2001) Dietary supplement use: consumer characteristics and interests. Journal of Nutrition 131, 1339S-1343S.

Hasler CM (2000) The Changing Face of Functional Foods. Journal of the American College of Nutrition 19, 499S-506S.

Hathcock JN (1997) Vitamins and minerals: efficacy and safety. American Journal of Clinical Nutrition 66, 427-437.

Hilliam M (1996) Functional Foods: the Western consumer viewpoint. Nutrition Reviews 54, S189-S194.

Jacobson MF \& Silverglade B (1999) Functional foods: health boon or quackery? British Medical Journal 319, 205-206.

Jonas MS \& Beckmann SC (1998) Functional Foods: Consumer Perceptions in Denmark and England. MAPP working paper no. 55. Aarhus, Denmark: Centre for Market Surveillance, Research and Strategy for the Food Sector.

Kirk SFL, Cade JE, Barrett JH \& Conner M (1999) Diet and lifestyle characteristics associated with dietary supplement use in women. Public Health Nutrition 2, 69-73.

Kristal AR, Hedderson MM, Patterson RE \& Neuhouser ML (2001) Predictors of self-initiated, healthful dietary change. Journal of the American Dietetic Association 101, 762-766.

Lyle BJ, Mares-Perlman JA, Klein BE, Klein R \& Greger JL (1998) Supplement users differ from nonusers in demographic, lifestyle, dietary and health characteristics. Journal of Nutrition 128, 2355-2362.

Milner JA (1999) Functional Foods and Health Promotion. Journal of Nutrition 129, 1395S-1397S.

Neuhouser ML, Patterson RE \& Levy L (1999) Motivations for using vitamin and mineral supplements. Journal of the American Dietetic Association 99, 851-854.

Ocké MC, Bueno-de-Mesquita HB, Goddijn HE, Jansen A, Pols MA, van Staveren WA \& Kromhout D (1997) The Dutch EPIC food frequency questionnaire. I. Description of the questionnaire, and relative validity and reproducibility for food groups. International Journal of Epidemiology 26, Suppl. 1, S37-S48.

Patterson RE, Neuhouser ML, White E, Hunt J \& Kristal AR (1998) Cancer-related Behavior of Vitamin Supplement Users. Cancer Epidemiology, Biomarkers and Prevention 7, 79-81.

Pitman S \& Reinhardt W (2000) Functional Foods: Attitudinal Research. Washington, DC: International Food Information Council (IFIC) Foundation. 
Radimer KL, Subar AF \& Thompson FE (2000) Nonvitamin, nonmineral dietary supplements: issues and findings from NHANES III. Journal of the American Dietetic Association 100, 447-454.

Sparling MC \& Anderson JJB (2001) Modified Foods in the Marketplace. Nutrition Today 36, 212-214.

Wallström P, Elmståhl S, Hanson BS, Östergren P-O, Johansson
U, Janzon L \& Larsson SA (1996) Demographic and psychosocial characteristics of middle-aged women and men who use dietary supplements. European Journal of Public Health 6, $188-195$.

Wrick KL (1995) Consumer issues and expectations for functional foods. Critical Reviews in Food Science and Nutrition 35, 167-173. 